\title{
An Investigation The Perceived Stress, University Adjustment Levels and Academic Grade Average of Freshman Nursing University Students
}

\author{
Hemşirelik Birinci Sınıf Öğrencilerinin Algıladıkları Stres İle \\ Üniversiteye Uyum Düzeyleri ve Akademik Genel Not \\ Ortalamaları Arasındaki İlişkinin İncelenmesi
}

\author{
Ayfer Öztürk
}

\begin{abstract}
:
Intense stress and adaptation problems experienced by students in the first year of university are important issues that attract attention in the literature. In this study, it was aimed to examine the relationship between the perceived stress, level of adaptation to the university and academic grade average. All freshman students $(n=70)$ studying at the Nursing Department in a government university in the 2019-2020 academic year participated in this study. The data were collected by using a Student Information Form, the Perceived Stress Scale, and the University Adjustment Scale. The mean age of the students is $19.35 \pm 2.82$ years, $67.6 \%$ of them are female and $98.5 \%$ are single. $66.2 \%$ of them stated that they wanted to study in the university they are enrolled in to a degree, $48.5 \%$ of them stated that they wanted to study in the department they currently study in to a degree, and $83.8 \%$ of them stated that they moved from a different city to study at the university. The average score of the students' compliance with the university is $93.80 \pm 15.63$ and is at a low level. The average score of the perceived stress level is $26.17 \pm 5.76$, which is high. There is a statistically significant and negative correlation between perceived stress and university adjustment levels $(r=-0.46, p<0.01)$. There was no significant relationship between students' academic grade point averages and adaptation to university and the perceived stress ( $p>0.05$ ). It is recommended that orientation programs be provided to incoming university students, and counseling services should be extended within the scope of the university's guidance and psychological counseling commissions and associated faculties.
\end{abstract}

Keywords: Stress, Nursing, University Students, University Adjustment, Grade Point Average

Assistant Professor of Nursing Department, Faculty of Health Sciences, Bartın University, Bartın, Turkey, Orcid İd: https://orcid.org/ 0000-0002-3092-0671

Address of Correspondence/Yazışma Adresi: Nursing Department, Faculty of Health Sciences, Bartın University, Bartın, Turkey, E-mail: ayferozturk.83@yahoo.com

Date of Received/Geliş Tarihi: 19.08.2020, Date of Revision/Düzeltme Tarihi: 16.10.2020, Date of Acceptance/Kabul Tarihi: 16.11.2020, Date of Online Publication/Çevirimiçi Yayın Tarihi: 27.11.2020

Citing/Referans Gösterimi: Öztürk, A. (2020). An Investigation The Perceived Stress, Unıversity Adjustment Levels and Academic Grade Average of Freshman Nursing University Students., Cyprus Turkish Journal of Psychiatry \& Psychology, 2(3): 155-62.

(C) 2020 The Author(s). Published by Cyprus Mental Health Institute / Cyprus Turkish Journal of Psychiatry and Psychology (www.ktppdergisi.com). This article is an open access article distributed under the terms and conditions of the Creative Commons Attribution 4.0 license which permits use, sharing, adaptation, distribution and reproduction in any medium or format, provided the original work is properly cited and is not used for commercial purposes. http://creativecommons.org/licenses/by/4.0/ 


\section{Özet:}

Öğrencilerin üniversitenin ilk yılında yaşadıkları yoğun stres ve uyum sorunları literatürde ilgi gören önemli konulardır. Bu çalışmada üniversiteye yeni başlayan hemşirelik bölümü öğrencilerinin algıladıkları stres ve üniversiteye uyum düzeyleri ile akademik genel not ortalamaları arasındaki ilişkinin incelenmesi amaçlanmıştır. Tanımlayıcı nitelikteki bu araştırmaya 2019-2020 eğitim-öğretim yılında bir devlet üniversitesinin Hemşirelik bölümünde öğrenim gören bütün birinci sınıf öğrencileri $(n=70)$ katılmıştır. Araştırma verileri Öğrenci Demografik Bilgi Formu, Algılanan Stres Ölçeği ve Üniversiteye Uyum Ölçeği kullanılarak toplanmıştır. Öğrencilerin yaş ortalaması $19.35 \pm 2.82$ yıldır. Öğrencilerin, \%67.6'sı kız, \%98.5'i ise bekardır. Öğrencilerin üniversiteye uyum puan ortalamaları $93,80 \pm 15,63$; algilanan stres düzeyi puan ortalamaları ise $26,17 \pm 5,76$ olarak bulunmuştur. Algılanan stres ile üniversiteye uyum düzeyleri arasinda istatistiksel olarak anlamlı ve negatif yönde bir ilişki bulunmaktadır $(\mathrm{r}=-0.46, \mathrm{p}<0.01)$. Öğrencilerin akademik genel not ortalamaları ile üniversiteye uyum ve algıladıkları stres arasında anlamlı ilişki saptanmamıştır ( $\mathrm{p}>0.05)$. $\mathrm{Bu}$ çalışmada üniversiteye yeni başlayan öğrencilerin algıladıkları stresin yüksek olduğu ve uyum olumsuz etkilediği bulunmuştur. Üniversiteye yeni başlayan öğrencilere oryantasyon programlarının uygulanması, üniversite ve ilgili fakültelerin rehberlik ve psikolojik danışma komisyonları faaliyetleri kapsamında danışmanlık hizmetlerinin yaygınlaştırılması ve stresi yönetmeye yönelik eğitimler verilmesi önerilmektedir.

Anahtar Kelimeler: Stres, Hemşirelik, Üniversite Öğrencileri, Üniversite Yaşamına Uyum, Akademik Genel Not Ortalamas1

\section{Giriş}

İnsanlar en uzun süre, öğrenci nüfusunun herhangi bir stres veya sorundan en az etkilenen kesim olduğunu varsaydılar(Masih ve Gulrez, 2006). Stres, artık gelişim aşamasından bağımsız olarak herhangi bir bireyi etkileyen bir yaşam tarzı krizi olarak anlaşılmaktadır (Banerjee ve Chatterjee, 2016). Öğrencilerin üstlenmeleri beklenen tek görev ders çalışmaktı ve ders çalışmak asla stresli olarak algılanmadı. Stresli olduğu ortaya çıkan şey, ebeveynlerin çocukları için beklentileriydi ve bu da, bu çocukların artık taşıyamayacakları daha büyük yüklere dönüştü.

Akademik stres, bu endişe verici rakamların birincil nedeni olarak tanımlanmıştır. Lee ve Larson (2000), bu stresi, çevresel stres faktörleri, öğrencinin değerlendirmesi ve buna yönelik tepkiler arasındaki bir etkileşim olarak açıklamaktadır. Artık "kariyer durdurucu" olarak adlandırılan ciddi bir gerçeklik haline geldiği ifade edilmektedir (Kadapatti \& Vijayalaxmi, 2012). Bu nedenle, yapılan araştırma da artan zihinsel sağlık endişelerinin belirtisi olduğu için önemli bir endişe nedeni haline gelmektedir.

Depresyon, anksiyete, davranış sorunları, sinirlilik vb. yüksek akademik stresi olan ögrencilerde bildirilen birçok sorundan birkaçıdır (Deb, Strodl ve Sun, 2015). Konsantre olamama, başarısızlık korkusu, geleceğin olumsuz değerlendirilmesi vb. ile bağlantıli olduğu içindir (Busari, 2012).

Ayrıca, düşük stresin öğrencilerin daha iyi performans göstereceklerini kesinleştirmediğini anlamak zorunlu hale gelmektedir. Ancak bu koşullar altında görevi rakipsiz olarak algilarlar ve kolayca sıkılabilirler (Uchil, 2017). Belli seviyelerdeki stres öğrencileri optimum performansa doğru itse de, stresle başa çıkmak için yetersiz kaynaklar nedeniyle verimli bir şekilde yönetilmediğinde, öğrenci ve kurum için iç karartıcı sonuçlar doğurabilir.

Her birey tarafindan ortaya çıkan stres tepkisi, tetikleyiciye neden olan şeyden bağımsız olarak aynıdır. Örneğin, evlilik stresi, sınav kaygısı, iş stresi vb. vücuttan aynı fizyolojik tepkileri ortaya çıkaracaktır. Bunun başlica nedeni, sinir sistemimizin sempatik bölünmesinin bir parçası olan adreno-medüller sistem ve adrenokortikal eksenin (Bourne \& Yaroush, 2003) "savaş ya da kaç" reaksiyonuyla sonuçlanmasıdır. Vücutta görülebilen fizyolojik değişikliklerden bazıları kalp atış hızı (HR), kan basınc1 (BP), solunum hızı, iskelet kaslarına doğru artan kan akışı vb. belirtilerdir.

Stres tepkisi aynı olsa da, bireyler tarafindan bildirilen stres kaynakları farklılık gösterir. $\mathrm{Bu}$ farklılıklar, stresörlerin nedenleri, kaynakları ve sonuçlarında görülecektir. Akademik bir ortamda bildirilen yaygın stres faktörlerinden bazıları aşırı ödevler, zayıf zaman yönetimi ve sosyal beceriler, akran rekabeti vb. içerir (Fairbrother \& Warn, 2003).

Diğer bireysel spesifik faktörler arasında finansal yönetimdeki sorunlar, yaşam ortamındaki değişiklikler, kişisel ve akademik yaşamı yönetme zorlukları vb. yer almaktadır (Chernomas ve Shapiro, 2013; Goff, 2011; Jimenez, Navia-Osorio ve Diaz , 2010; Moscaritolo, 2009).

Eğitim sistemi ayrıca, daha sonra öğrencilerin yaşadığı stres düzeylerinin artmasına yol açan, kolaylaştırıcı bir rol oynar. Kaynakların bazıları arasında aşırı kalabalık konferans salonları, dönem not sistemi, yetersiz kaynaklar ve tesisler (Awino \& Agolla, 2008), müfredatın genişliği, uzun saatler ve ezberci öğrenmenin beklentileri bulunmaktadır (Deb vd., 2015). Ebeveynler ve kurumlar, özgüvenlerini etkileyen başarısızlık korkusunu acımasızca aşlarlar. Ang \& Huan (2006), artan stres seviyelerinden sorumlu faktörlerden biri olarak artan beklentileri bildirmiştir.

$\mathrm{Bu}$ nedenle, stres kaynakları vücut tarafindan ortaya çıkan özdeş stres tepkilerine rağmen değiştiğinden, birincisinin anlaşılması, öğrencilerin stres düzeylerini azaltmayı hedefleyen kişiye özel müdahalelerin geliştirilmesine yardımcı olacak ve bu da bireyin bütünsel iyiliğine katkıda bulunacaktır.

Alan yazında akademik not ortalaması puanları ile üniversiteye uyum ve algılanan stres düzeyleri arasında ilişki olduğunu gösteren çalışmalar mevcuttur (Mercan ve 
Yıldız, 2011; Sevim ve Yalçın, 2006). Örneğin Mercan ve Yıldız'ın birinci sınıf öğrencileri ile gerçekleştirdikleri çalışmada (2011), akademik başarı düzeyi ile üniversite ortamına uyum, akademik uyum ve sosyal uyum boyutları arasında anlamlı ilişki olduğu belirlenmiştir.

Yine farklı araştırmalarda hemşire okulu öğrencilerinin stres yaşama düzeylerini yüksek olduğu, final sınavı, klinik sınav uygulamaları, akademik yönden endişeleri ve derslerin genel yükünün normal hemşirelik görevleriyle birlikte geldiğinde stres düzeylerinde artış gösterdiği bulunmuştur (Olgun ve ark. 2010). Hemşire okulu öğrencilerinde, uzun dönemde kontrol altına alınamayan sağlık sorunlarının hayatlarını olumsuzu etkilediği (Altiok ve Ustun, 2013; Edwards ve ark., 2010), ayn1 zamanda stresten kaynaklı olarak karar alma, düşünme gibi yeteneklerinde zayıflama ortaya çıktığı ve bu durumun kendilerinin akademik başarılarını düşürdüğü ortaya çkmıstır. Diğer taraftan hemşirelik okulu öğrencilerde hipertansiyon, kalp hastalığı ve bağışıklık sisteminin zayıflaması gibi çok daha riskli durumların yaşanmasına neden olduğu yapılan çalışmalarda bildirilmektedir (Maville, Kranz ve Tucker, 2004; Lee, Holzemer, Faucett, 2007; Karaca ve ark. 2017).

Literatür bilgisinden yola çıkarak bu çalışmanın amacı, akademik yaşamın hemşirelik okulu öğrencileri üzerine yüklediği stresin ölçülmesi ve algılanan stres düzeyi ile öğrencilerin üniversiteye uyumları ve akademik not ortalamaları arasında bulunan ilişkinin araştırılmasının yapılmasıdır. $\mathrm{Bu}$ amaçla, çalışmada aşağıdaki soruların cevapları aranacaktır:

1) Hemşirelik lisans öğrencilerinin algıladığı stres düzeyi ne durumdadir?

2) Hemşirelik lisans öğrencilerinin algıladıkları stres düzeyi ve üniversiteye uyum düzeyleri arasında ilişki var midir?

3) Hemşirelik lisans öğrencilerinin algıladıkları stres düzeyleri ve akademik genel not ortalamaları arasında ilişki var mıdır?

4) Hemşirelik lisans öğrencilerinin üniversiteye uyumları ile akademik genel not ortalamaları arasında ilişki var midir?

\section{Yöntem}

\section{Katılımcilar}

Araştırmanın evrenini 2019-2020 eğitim öğretim yılı güz döneminde bir devlet üniversitesinin hemşirelik bölümünde öğrenim gören lisans öğrencileri oluşturmaktadır. Hemşirelik bölümü yeni açılmış olup sadece 1. sınıf öğrencileri bulunmaktadır. $\mathrm{Bu}$ nedenle örneklem seçimine gidilmeyip tüm birinci sınıf öğrencilerine ulaşılması hedeflenmiş ve 70 öğrenci ile araştırma tamamlanmıştır.

\section{Veri Toplama Araçları}

Tanıtıcı Bilgi Formu: Öğrencilerin yaş, cinsiyet, medeni durum, ebeveyn hakkında bilgi (yaşam durumu, eğitim düzeyi, meslek, gelir düzeyi), şu anda yaşamakta oldukları yer (ev, yurt vs), eğitim boyunca masrafların nasıl karşılandığı, üniversite okumak için şehir değiştirme durumu, seçtikleri üniversite ve bölümü isteme durumları hakkında bilgi edinmeye yönelik toplam 13 sorudan oluşan bir formdur.
Algılanan Stres Ölçeği (ASÖ): Cohen, Kamarck ve Mermelstein (1983) tarafindan öznel stresi değerlendirmek için geliştirilen ölçek, 5'li Likert türünde 14 maddeden oluşmaktadır. Türkçeye ölçek uyarlaması için Eskin, Harlak, Demirkıran ve Dereboy (2013) tarafından yapılmış ve tek faktör olarak kullanılan ölçeğin 2 faktörlü bir yapıya sahip olduğu belirlenmiştir: yetersiz öz yeterlik algısı ve stres / rahatsızlık algısı. Ölçeğin amacı, bireylerin son bir ay içinde yaşadıkları deneyimler hakkında nasıl düşündüklerini ve hissettiklerini ortaya çıkarmaktır. Öğeler kolayca anlaşılır ve toplumun her düzeyindeki bireylere kolayca uygulanabilir. Ölçeğin 4 ve 10 maddelik versiyonları bulunmaktadır. $\mathrm{Bu}$ araştırmada kullanılan 14 maddeden oluşan formda, maddeler, katılımcılar tarafindan 0 (hiçbir zaman) ile 4 (sıklıkla) arasında değerlendirilmekte ve ölçekten alınabilecek puan 0 ile 46 arasında değişmektedir. 7 ile 9,10 ve 13 ölçeğin tersi puanlanmıştır. Algılanan stres düzeyinin ortalama puanı kesme noktası olarak alınır ve algılanan stres düzeyi bu puanın altında veya üstünde belirlenir. Uyarlama çalışmasında ölçeğin tamamının iç tutarlılık katsayısı 0.82 , test-tekrar test güvenirlik katsayısı ise 0.88 'dir. $\mathrm{Bu}$ çalışmada ölçeğin iç tutarlık katsayısı 0,84 olarak bulunmuştur.

Üniversiteye Uyum Ölçeği (ÜUÖ): Sevinç-Tuhanioğlu (2017) tarafindan birinci sınıf öğrencilerinin üniversite yaşamına uyumlarını ölçmek için geliştirilen Üniversite Uyum Ölçeği sırasıyla 45 maddeden; akademik uyum (12 madde), sosyal uyum (13 madde), kişisel / duygusal uyum (10 madde) ve kurumsal uyum (10 madde olarak adlandırılan 4 faktör içerir). Akademik yönelim, öğrencilerin bölümleriyle ilgili akademik yükümlülüklerini yerine getirme ve akademik ortamdan memnun olma becerisidir. Bu faktörle ilgili örnek madde: "Akademik deneyimim bölümüme olan ilgimi artırıyor" (madde 4). "Sosyal uyum" faktörü, öğrencilerin üniversitedeki arkadaşları ile ilişsilerini, kampüste sosyal hayata katılımlarını ve sosyal yaşamdan duydukları memnuniyeti ifade etmektedir. Bu faktöre ilişkin örnek madde: "Üniversitedeki arkadaşlarımla ilişkim çok iyi" (madde 2). Kişisel-duygusal uyum faktörü ise ögrencilerin duygu-durumlarını ifade etmektedir. $\mathrm{Bu}$ faktör için örnek madde: "Son zamanlarda hiçbir şey yapmak istemiyorum" (madde 7). Kurumsal uyum faktörü, öğrencilerin kurumlarından (üniversite) ve kuruma aidiyetlerinden duydukları memnuniyeti ifade eder. Bu faktöre ilişkin örnek madde: "Bu üniversiteyi seçerek doğru kararı verdiğimden emin değilim" (madde 4). Ölçekte yer alan 21 madde tersten puanlanmaktadır. Bu maddeler sirasiyla 3., 4., 6., 7., 8., 11., 14., 15., 16., 19., 23., 24., 27., 28., 32., 33 Kat1limcilar, 36, 39, 40, 41 ve 42 , ilgili maddelere 7'li Likert tipi derecelendirme ile cevap verirler ve ölçekten alınabilecek en düşük puan 45 ve en yüksek puan 315 'dir. ölçek öğrencilerin üniversiteye yüksek düzeyde uyum sağladığını, düşük puanlar ise düşük düzeyde uyum sağladığını göstermektedir (Tuhanioğlu 2017). Ölçeğin Cronbach alfa değeri Academic Fit için 0,90; Sosyal Uyum için 0.87; Kurumsal Uyum için 0,91 ve Kişisel Uyum için 0,89 olarak hesaplanır. Ölçeğin tamamı ve kapsadığı tüm boyutlar için Cronbach alfa değeri 0,93 olarak belirlenmiştir. Bu çalışmada ölçeğin toplam Cronbach alfa değeri 0.88 olarak hesaplanmıştır.

\section{Etik Prosedür}

Araştırmanın başlatılabilmesi için öncelikle Bartın Üniversitesi Etik Kurul'undan etik onay (2020-01) 
alınmıştır. Sonrasında ölçeklerin uygulanabilmesi için Bartın Üniversitesi Sağlı Bilimleri Fakültesi Dekanlı̆̆ı'’ndan izin alınmıştır. Anket ve ölçek formları öğrencilere ders saatleri açısından uygun görülen saatlerde sınıf ortamında fakültenin Psikolojik Rehberlik ve Danışma Komisyonu'nda görevli Psikiyatri Hemşireliği Anabilim Dalı öğretim üyesi tarafından yüz yüze olarak uygulanmıştır. Ölçeklerin doldurulması ortalama 15-20 dk sürmüştür

\section{Verilerin Analizi}

Araştırmada elde edilen datalar, SPSS 23.0 istatistik programı aracılığıyla analize tabi tutulmuştur. Değişkenlerle birlikte ortalama ve standart sapmanın yanı sıra kategorik değişkenlerde sayılar ve yüzdeler olarak ifade edilmiştir. Ayrıca sürekli değişkenlerin kendi aralarındaki ilişkinin araștırılmasında Pearson analiz tekniği kullanılmıștır. İstatistik yöntem uygulamasında $\mathrm{p}=<0.05$ 'in altındaki değerin anlamlı olarak kabul edilmiştir.

\section{Bulgular}

\section{Öğrencilerin Demografik Özellikleri}

Araştırmaya katılan öğrencilerin \%36.8'i (n=25) 18 yaşında, \%67.6's1 (n= 46) kadın ve büyük çoğunluğu $(\% 98.5 \mathrm{n}=67)$ bekardır. Öğrencilerin yaş ortalamas1 $19.35 \pm 2.82$ y1l olup, \%83.8'i $(n=57)$ üniversite eğitimi almak için ailesinden ayrılıp başka bir şehre gelmiştir ve \%72.1'i (n= 49) öğrenci yurdunda kalmaktadır. \%66.2'si $(n=45)$ okuduğu üniversiteyi, \%48.5'i $(n=33)$ okuduğu bölümü biraz istediklerini belirtmişlerdir (Tablo 1).

Tablo 1. Öğrencilerin tanıtıcı özellikleri

\begin{tabular}{|c|c|c|}
\hline & $\mathbf{n}$ & $\%$ \\
\hline \multicolumn{3}{|l|}{ Yaş } \\
\hline 18 & 25 & 36.8 \\
\hline 19 & 25 & 36.8 \\
\hline $20 \uparrow$ & 18 & 26.5 \\
\hline \multicolumn{3}{|l|}{ Cinsiyet } \\
\hline Erkek & 22 & 32.4 \\
\hline Kadin & 46 & 67.6 \\
\hline \multicolumn{3}{|l|}{ Medeni Durum } \\
\hline Bekar & 67 & 98.5 \\
\hline Evli & 1 & 1.5 \\
\hline \multicolumn{3}{|l|}{ Yaşadığı kişi } \\
\hline Yurt & 49 & 72.1 \\
\hline Evde (aile, arkadaş, akraba) & 19 & 27.9 \\
\hline \multicolumn{3}{|c|}{ Okuduğu üniversiteyi isteme durumu } \\
\hline Çok istedim & 7 & 10,3 \\
\hline Biraz istedim & 45 & 66.2 \\
\hline Hiç istemedim & 16 & 23.5 \\
\hline \multicolumn{3}{|c|}{ Okuduğu bölümü isteme durumu } \\
\hline Çok istedim & 27 & 39.7 \\
\hline Biraz istedim & 33 & 48.5 \\
\hline Hiç istemedim & 8 & 11.8 \\
\hline \multicolumn{3}{|c|}{ Üniversitede okumak için şehir değiştirme durumu } \\
\hline Evet & 11 & 16.2 \\
\hline Hayır & 57 & 83.8 \\
\hline \multicolumn{3}{|c|}{ Eğitim boyunca masrafları karşılama } \\
\hline Çalışıyorum & 1 & 1.5 \\
\hline Burs alıyorum & 27 & 39.7 \\
\hline Ailem karşılıyor & 40 & 58.8 \\
\hline \multicolumn{3}{|l|}{ Ailenin ortalama aylık geliri } \\
\hline 1000tl ve aşağısı & 6 & 8.8 \\
\hline $1000-2000 t 1$ arasi & 17 & 25.0 \\
\hline 2001-3000tl arasi & 20 & 29.4 \\
\hline 3001-4000tl arasi & 14 & 20.6 \\
\hline 4001tl ve yukarıs1 & 11 & 16.2 \\
\hline \multicolumn{3}{|l|}{ Anne öğrenim durumu } \\
\hline İlköğretim ve altı & 54 & 79.4 \\
\hline Lise & 8 & 11.8 \\
\hline Üniversite ve üstü & 6 & 8,8 \\
\hline \multicolumn{3}{|l|}{ Baba öğrenim durumu } \\
\hline İlköğretim ve altı & 33 & 48.5 \\
\hline Lise & 25 & 36,8 \\
\hline Üniversite ve üstü & 10 & 14.7 \\
\hline \multicolumn{3}{|l|}{ Annenin çalışma durumu } \\
\hline Evet & 12 & 17.6 \\
\hline Hayır & 56 & 82.4 \\
\hline \multicolumn{3}{|l|}{ Babanın mesleği } \\
\hline İşçi & 14 & 20.6 \\
\hline Memur & 12 & 17.6 \\
\hline Serbest meslek & 21 & 30.9 \\
\hline Emekli & 11 & 16.2 \\
\hline Çalışmıyor & 10 & 14.7 \\
\hline \multicolumn{3}{|l|}{ Anne sağ olma durumu } \\
\hline Evet & 66 & 97.1 \\
\hline Hayır & 2 & 2.9 \\
\hline
\end{tabular}

Öztürk, A. (2020). 
Öğrencilerin Üniversiteye Uyum Ölçeği puan ortalamaları $93.80 \pm 15.63$ olup, en az puanı kişisel/duygusal uyum (44.27 \pm 15.47$)$ alt boyutundan, en fazla puanı sosyal uyum alt boyutundan almışardır (65.19 \pm 14.58$)$. Bu sonuçlar öğrencilerin üniversiteye uyumlarının düşük olduğunu göstermektedir (Tablo 2). Öğrencilerin Algılanan Stres Ölçeği toplam puan ortalaması $26.17 \pm 5.76$ olup yüksek düzeydedir. Öğrencilerin akademik genel not ortalamaları (AGNO) $2.48 \pm 0.56$ olarak saptanmıştır (Tablo 2).

Tablo 2. Öğrencilerin üniversiteye uyum ölçeği, algılanan stres ölçeği toplam ve alt boyut puan ortalamaları ile akademik genel not ortalamaları

\begin{tabular}{llll}
\hline & $\mathbf{n}$ & Ortalama \pm Ss & Min-max \\
Akademik uyum & 68 & $56.48 \pm 10.71$ & $25.00-82.00$ \\
Sosyal uyum & 68 & $65.19 \pm 14.58$ & $28.00-91.00$ \\
Kurumsal uyum & 68 & $43.32 \pm 10.73$ & $18.00-64.00$ \\
Kişisel/Duygusal uyum & 68 & $44.27 \pm 15.47$ & $15.00-98.00$ \\
ÜUÖ Toplam puan & 68 & $93.80 \pm 15.63$ & $66.00-131.00$ \\
Öz yeterlilik & 68 & $11.38 \pm 4.08$ & $1.00-24.00$ \\
Stres algısı & 68 & $14.79 \pm 4.24$ & $4.00-24.00$ \\
ASÖ Toplam puan & 68 & $26.17 \pm 5.76$ & $12.00-38.00$ \\
AGNO & 68 & $2.48 \pm 0.56$ & $0.83-3.37$ \\
\hline
\end{tabular}

Öğrencilerin AGNO ile ÜUÖ ve ASÖ puan ortalamaları arasındaki ilişkiyi belirlemek üzere uygulanan Pearson Korelasyon analizi sonuçları incelendiğinde; öğrencilerin AGNO ile algilanan stres ve üniversiteye uyum puanları arasında istatistiksel olarak anlamlı bir ilişki saptanmamıştır $\quad(\mathrm{p}>0.05) \quad$ (Tablo 3). Öğrencilerin üniversiteye uyum toplam puan ortalamaları ile algilanan stres puan ortalamaları arasında ters yönde ilişkili bulunmuştur. Yani algılanan stres düzeyinin yüksek olması üniversite yaşamına uyum $(\mathrm{r}=-.46, \mathrm{p}<.01)$, akademik uyum $(\mathrm{r}=-.31, \mathrm{p}<.01)$ ve kişisel/duygusal uyum $(\mathrm{r}=-.54, \mathrm{p}<.01)$ ile negatif ilişkilidir.

Son olarak öğrencilerin üniversiteye uyum ve algıladıkları stres düzeylerinin akademik genel not ortalamalarını etkilemediği saptanmıştır $(\mathrm{r}=.23, \mathrm{p}>.05 ; \mathrm{r}=.08, \mathrm{p}>0-.05)$ (Tablo 3).

Tablo 3. Öğrencilerin Üniversiteye Uyum Ölçeği (ÜUÖ), Algılanan Stres Ölçeği (ASÖ) ve Akademik Genel Not Ortalamaları (AGNO) Arasındaki Korelasyon Analizi Sonuçları

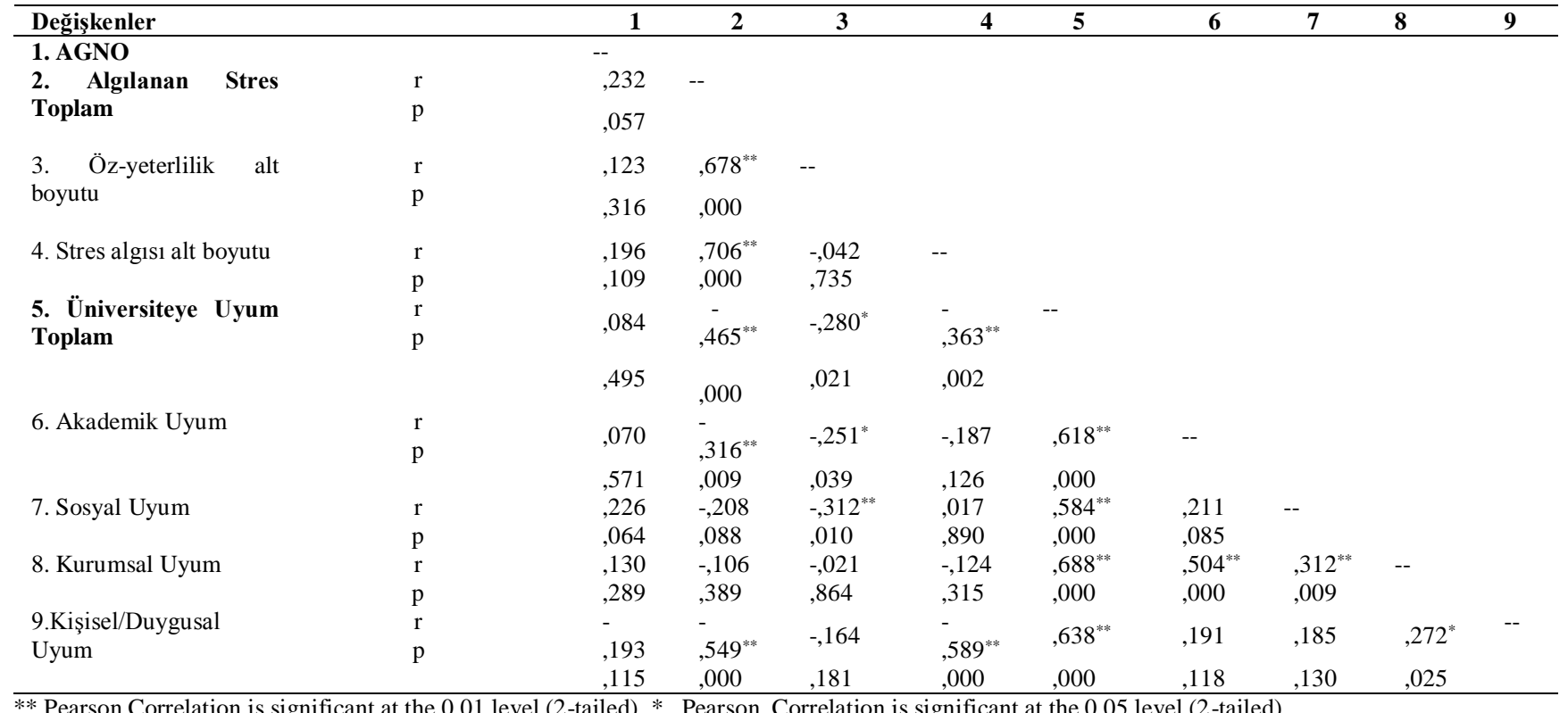

\section{Tartışma}

Üniversite öğrencileri arasında, özellikle birinci sınıflarında yoğun bir şekilde yaşadıkları stres ve uyum problemleri, literatürde çok fazla araştırılan konuların başında gelmektedir. Bu çalışmada, hemşirelik bölümü 1 . sınıf öğrencilerindeki algılanan stres ile üniversite hayatına uyumları arasındaki ilişki ve akademik genel not ortalamalarının nasıl etkilendiği incelenmiştir. Araştırma sonuçlarında, yeni başlayan hemşirelik bölümü 1. sınıf öğrencilerinde, üniversite yaşamına uyum düzeyleri düşük olup, yüksek düzeyde stres algılamaktadırlar. Bununla birlikte hemşirelik öğrencilerindeki algılanan stres seviyesi ile üniversiteye uyum durumları arasında negatif yönlü bir ilişki saptanmıştır. $\mathrm{Bu}$ açıdan bakıldığında, öğrencilerdeki algılanan stres düzeyi arttıkça üniversiteye uyum düzeyleri azalmaktadır. Araştırma bulgularımızı destekler nitelikte 1.sınıf üniversite öğrencilerin yaşadıkları uyum sorunu ise stres 
düzeyi arasında manidar bir ilişki olduğunu gösteren araştırmalar mevcuttur (Akhunlar-Turgut ve ark. 2018; Dyson ve Renk, 2006; Pancer ve ark., 2000). Çalışmalarda stres düzeyi yüksek olan 1.sınıf öğrencilerinde üniversiteye uyumlarına ait seviyenin düştüğü bulunmuştur (Clinciu, 2013; Dyson ve Renk, 2006). Diğer taraftan baş bir araştırma da sosyal ve akademik stres ile üniversiteye ait uyum değişkenleri arasında negatif bir ilişkinin olduğu ortaya çıkmıştır (Solberg ve ark. 1994). Gilliam ve diğerleri tarafından (2008) yapılan araştırmada ise, stresin akademiyle uyumu ve kişisel uyumu ile negatif ilişkide olduğu tespit edilmiştir. Hemşirelik bölümündeki araştırma da ise çoğunluk öğrencinin ilk yılında uyum zorluğu çektiklerini belirtmişlerdir (Cimete, 1998). 1.Sınıf hemşirelik öğrencileri arasındaki diğer bir çalışmada ise üniversite yaşamına uyum konusunda güçlükler yaşadıkları ortaya çıkarılmıștır (Karahan ve ark., 2005). Araștırma sonuçları literatür bulgularını desteklemektedir (buraya yukarıdaki referanslar eklenmeli). Örneğin, Özkan ve Yılmaz'ın (2010) çalışmasında öğrencilerin \%50.8'inin okudukları bölümden kısmen memnun olduğu ve \%19.0'nun üniversite yaşamına uyum sağlamada zorluk yaşadığı saptanmıştır. Benzer şekilde, bizim araştırma bulgularına göre de öğrencilerin büyük çoğunluğu okudukları üniversiteyi ve bölümü biraz istediklerini belirtmişlerdir. Öğrencilerin yeni bir çevre, farklı kişiler ve farklı bir eğitim tarzı çoğunlukla ilk kez karşılaşıyor olmaları, okudukları bölümü benimseyememeleri stres algılarını arttırabilecek ve üniversite yaşamına uyumlarını bozabilecek önemli faktörler olarak düşünülmektedir.

$\mathrm{Bu}$ araştırma da ise, AGNO, algılanan stres ve üniversite yaşamına uyum düzeyleri arasında anlamlı ilişki saptanmamıştır. Daha geniş örneklem grupları ile çalışılması önerilebilir.

\section{Sonuç ve Öneriler}

Üniversiteye uyum konusu literatürde çok sıklıkla ele alınan ve farklı değişkenlerle bir arada incelenen bir başlık olmakla birlikte güncelliğini korumaktadır. Bu araştırmada da hemşirelik birinci sınıf öğrencilerinin üniversiteye uyumları, algıladıkları stres ve AGNO ile karşılaştırılmıştır. Bu araştırmanın sonucunda üniversite ilk sınıf hemşirelik okulu öğrencilerinin algıladıkları stres düzeyi yüksek bulunduğudur. Diğer taraftan uyum aşamasında değişik problemler yaşadıkları ortaya çıkmıştır. Üniversite yaşamına uyum süreci, karmaşık ve çok boyutlu doğası gereği, akran, öğretim elemanı, üniversite personeli, ve yönetici gibi çeşitli sosyal destek kaynaklarının etkin bir şekilde sürece dahil olması gerekmektedir. $\mathrm{Bu}$ süreçte, tüm bu sosyal destek kaynaklarının işbirliği içerisinde önleyici ve gelişimsel çalışmaları gerçekleştirmeleri ve belirli aralıklarla bu faaliyetlerin etkililiklerinin değerlendirilmesi önemlidir. Öğrencilerin stresle başa çıkma becerilerini güçlendirmek için strese neden olabilecek durumları tanımaya ve kendilerini tanımaya yönelik eğitim programları düzenlenmelidir. Ayrıca eğitimcilerin öğrencilerin yaşadıkları stres ve başa çıkma stratejileri konusundaki farkındalıkları artırılmalıdır. Eğitim programlarına ek olarak, hemşirelik öğrencilerinin başa çıkma becerilerini geliştirmek için psiko-eğitimsel ve psikolojik danışmanlık sunulabilir.

Topluma yön veren üniversite öğrencilerinin stres düzeylerinin ve üniversiteye uyumlarının belirlenmesi önemlidir. Üniversitenin ilk yllından başlanarak öğrencilerin algıladıkları stres düzeyinin belirlenmesi, algıladıkları stresi azaltmaya yönelik baş etme yöntemleri konusunda eğitim verilmesi ve danışmanlık yapılması öğrencinin üniversite hayatından elde ettiği kalite ve verimi artırabilmesi açsından önem arz etmektedir. $\mathrm{Bu}$ çalışmadan elde edilen bulguların üniversitelerin Psikolojik Danışma ve Rehberlik Merkezleri veya fakültelerin Rehberlik ve Psikolojik Danışma Komisyonları tarafindan üniversiteye uyum süreciyle ilgili gerçekleştirilen önleyici ve gelişimsel çalışmalara ve üniversiteye uyum kapsamında yürütülen programların temel önceliklerinin belirlenmesine katkı sunabileceği düşünülmektedir.

Son olarak, ileriki çalışmalarda korelasyon bulgularında, değişkenler arasındaki ilişkideki olası aracı faktörlerin rolünün araştırılması önerilebilir.

\section{Araştırmanın Sınırlılıkları}

$\mathrm{Bu}$ araştırmanın örneklemi hemşirelik bölümü birinci sınıf öğrencilerinden oluşmaktadır. Elde edilen veriler tüm üniversite öğrencilerine genellenemez. Elde edilen sonuçların Türkiye genelindeki üniversite öğrencileri üzerinde genellenebilmesi için farklı fakülte/Yüksekokullarda farklı araştırma teknikleri kullanılarak yeni araştırmaların yürütülmesine ihtiyaç duyulmaktadır.

\section{Beyannameler}

\section{Etik Onay ve Katılma İzni}

Araşıtımanın başlatılabilmesi için öncelikle Bartın Üniversitesi Etik Kurul'undan etik onay (2020-01) alınmıştır.

\section{Yayın İzni}

Uygulanmaz.

Veri ve Materyallerin Mevcudiyeti

Mevcut çalışma sırasında kullanılan ve / veya analiz edilen veri kümeleri, makul talep üzerine ilgili yazardan temin edilebilir.

\section{Çıkar Çatışması}

Yazarlar çıkar çatışması olmadığını beyan eder.

\section{Finansman}

Uygulanamaz.

Yazar Katkıları

AÖ, araştırma verilerini toplamış, analiz etmiş ve yorumlamıştır. Makaleyi yazmış son halini okumuş ve onaylamıştır.

Teşekkür

Uygulanmaz.

\section{Kaynaklar}

Ang, R. P. \& Huan, V.S. (2006). Akademik stres ve intihar düşüncesi arasındaki ilişki Çoklu regresyon kullanarak bir aracı olarak depresyon testi. Çocuk psikiyatrisi ve insan gelişimi. 37 (2): 133-143.

Awino, J. O. \& Agolla, J.E. (2008).Üniversiteler için sürdürülebilir kalite güvence ölçümü arayışı: Botsvana Üniversitesi'nin çalışma örneği. Res. Rev. 3 (6): 213-218.
Banerjee, N.C., Akademik Stres İntihar Düşüncesi ve Ruh WellBeing st Dönemi \& 3 rd Dönem Medikal, Mühendislik ve Genel Akış öğrenciler. Araştırmacılar Dünyası. 2012 ; 73-80. Https://search.proquest.com/docview/1816764514?pqorigsite $=$ gscholar adresinden erişildi

Bourne, L. E. \& Yaroush, R.A. (2003). Stres ve biliş: Bilişsel psikolojik bir bakış açısı. Yayınlanmamış el yazması. NASA NAG hibe. 2-1561. 
Http://ntrs.nasa.gov/archive/nasa/casi.ntrs.nasa.gov/2004003407 0 .pdf adresinden erişildi.

Busari, A.O. (2012) Ergenlerde Cinsiyet Yaş Depresyonu ile Akademik Performans Arasındaki İlişkinin Değerlendirilmesi. Scholarly Journal of Education . 1 (1) : 6-12.

Deb, S., Strodl, E. \& Sun, J.(2015). Hintli lise öğrencileri arasında akademik stres, ebeveyn baskıs1, kayg1 ve zihinsel sağlık. Uluslararası Psikoloji ve Davranış Bilimleri Dergisi 5 (1): 26-34.

Chernomas, W. M. \& Shapiro, C. (2013).Hemşirelik lisans öğrencilerinde stres depresyonu ve anksiyete. Uluslararası hemşirelik eğitimi bursu dergisi. 10 (1): 255-266.

Fairbrother. K, \& Warn, J. (2003)İşyeri stresi ve iş tatminini boyutlandırır. Yönetim psikolojisi dergisi 18 (1): 8-21.

Goff, A.M. (2011). Bakalorya hemșireliği öğrencilerinde Stresörler, akademik performans ve öğrenilen beceriklilik. Uluslararası Hemșirelik Eğitimi Bursu Dergisi 8 (1).

Jimenez, C., Navia - Osorio, P. M. \& Diaz, C.V. (2010). Acemi ve deneyimli hemşirelik öğrencilerinde stres ve sağlı. İleri Hemşirelik Dergisi 66 (2): 442-455.

Kadapatti, M.G. \& Vijayalaxmi, A.H.M. (2010). Akademik Stres Stresörleri- Üniversite Öncesi Öğrenciler Üzerine Bir Araştırma. Hint Bilimsel Araştırma Dergisi 3 (1) : 171-175.

Lee, M. \& Larson, R. (2000). Koreli 'Sınav Cehennemi' Uzun Çalışma Saatleri Sıkıntı ve Depresyon.

Masih, P. P. \& Gulrez, N.K. (2006). Stres üzerine yaş ve cinsiyet farklılıkları. İnsan stres yönetiminde son eğilimler 97-104

Moscaritolo, L.M. (2009). Klinik öğrenme ortamında hemșirelik öğrencilerinin kaygısını azaltmak için girişimsel stratejiler. Hemşirelik ĕgitimi dergisi 48 (1): 17.

Uchil, H.B. (2007). Stresin Öğrenci Performansına Etkisi. Stres Yönetimi Profesyonel Uluslararası Dergisi 5 (1): 17-21.

Akhunlar-Turgut, M.N., Sarıot- Ertürk, Ö., Karslı, F., Şakiroğlu, M. (2020). Algılanan Stres ve Üniversite Yaşamına Uyum İlişkisinde Bir Aracı Değişken: Ayrılık Anksiyetesi. Hacettepe Üniversitesi Ĕ̆itim Fakültesi Dergisi (H. U. Journal of Education, 35(2), 338-353.

Altiok, H.O. ve Ustun, B. (2013). The stress sources of nursing students. Educational Sciences: Theory \& Practice, 13(2), 74766.

Alpan, A. (1992). Cumhuriyet üniversitesi ve Erciyes üniversitesi fen edebiyat fakültesi öğrencilerinde çevreye ve üniversiteye uyum sorunları. Yayımlanmamış Yüksek Lisans Tezi. Cumhuriyet Üniversitesi Sosyal Bilimler Enstitüsü, Sivas.

Baker, S.R. (2003) A prospective longitudinal investigation of social problem $\neg$ solving appraisals on adjustment to university, stress, health, and academic motivation and performance. Personality and Individual Differences, 35 (3), 569-591.

Bean, J. P. (1980). Dropouts and turnover: The synthesis and test of a causal model of student attrition. Research in Higher Education, 12 (2), 155-187.

Bean, J. P. (1983). The application of a model of turnover in work organizations to the student attrition process. The Review of Higher Education, 6 (2), 129-148

Brooks, H. J. \& Dubois, L. D. (1970). Individual and environmental predictors of adjustment during the first year of college. Journal of College Student Development, 36(4), 347360 .

Bülbül, T., Acar-Güvendir, M. (2014). Üniversite Birinci Sınıf Öğrencilerinin Yükseköğretim Yaşamına Uyum Düzeylerinin İncelenmesi. Eğitim Bilimleri Araştırmaları Dergisi, 4(1), 398410 .

Cimete, G. (1998). "Ögrenci-Ögretim Elemanı Etkilesimine Yönelik Kalitatif Bir Çalısma", C.Ü. Hemsirelik Yüksekokulu Dergisi, 2 (1), 9-19.
Clinciu, A. I. (2013). Adaptation and stress for the first year university students. Procedia-Social and Behavioral Sciences, $78,718-722$

Cohen, S., Kamarck, T. ve Mermelstein, R. (1983). A global measure of perceived stress. Journal of Health and Social Behavior, 24(4), 385-396.

Dyson, R. \& Renk, K. (2006). Freshmen adaptation to university life: Depressive symptoms, stress, and coping. Journal of Clinical Psychology, 62, 1231-1244.

Durna, U. (2006). Üniversite öğrencilerinin stres düzeylerinin bazı değişkenler açısından incelenmesi. İktisadi ve İdari Bilimler Dergisi, 20(1), 319-343.

Edwards, D., Burnard, P., Bennett, K., Hebden, U. (2010). A longitudinal study of stress and self-esteem in student nurses. Nurse Educ Today, 30,78-84.

Eskin, M., Harlak, H., Demirkıran, F. ve Dereboy, Ç. (2013). Algılanan Stres Ölçeğinin Türkçeye Uyarlanması: Güvenirlik ve Geçerlik Analizi. New/Yeni Symposium Journal, 132-140.

Fisher, S. \& Hood, B. (1987). The stress of the transition to university: A longitudinal study of psychological disturbance absent-mindedness and vulnerability to homesickness. British Journal of Psychology, 78(4), 425-441.

Gilliam, A. K., Barry, McNamara, C. ve Bacchus, N. A. (2008) "The relationship between stress and college adjustment: the moderating role of spirituality," Modern Psychological Studies, $13(2)$

Hancıoğlu, Y. (2017). Üniversite Öğrencilerinin Algıladıkları Stres Düzeyleri ile Stresle Başa Çıkma Tarzları Arasındaki İlişkinin İncelenmesi. Yönetim ve Ekonomi Araştırmaları Dergisi, 15 (1), 130-149.

Hegge, M., Larson, V. (2008). Stressors and coping strategies of students in accelerated baccalaureate nursing programs. Nurse Education, 33(1), 26- 30

Karaca A, Yildirim N, Ankarali H, Açikgöz F ve Akküz D. (2017). Hemşirelik Öğrencilerinin Algılanan Klinik Stres Düzeyi, Stres Cevapları ve Bașetme Davranıșları. Psikiyatri Hemşireliği Dergisi, 8 (1), 32-39.

Karahan, T. F., Sardoğan, M. E., Özkamalı, E. \& Dicle, A. N. (2005). Üniversite 1. sinıf öğrencilerinin üniversiteye uyum düzeylerinin sosyokültürel etkinlikler açısından incelenmesi. Çukurova Üniversitesi Ĕ̈itim Fakültesi Dergisi, 2 (30), 63-72.

Lee, M.H., Holzemer, W.L., Faucett, J. (2007). Psychometric evaluation of the Nursing Stress Scale (NSS) among Chinese nurses in Taiwan. $J$ Nurs Meas, 15,133-44.

Levitz, R., \& Noel, L. (1989). Connecting students to institutions. In The freshman year experience. M. L. Upcraft and J. N. Gardner (eds.). San Francisco: Josey-Bass.

Maville, J.A., Kranz, P.L., Tucker, B.A. (2004). Perceived stress reported by nurse practitioner students. J Am Acad Nurse Pract, $16,257-62$.

Mercan, S. Ç. \& Yıldız, A. S. (2011). Eğitim fakültesi birinci sınıf öğrencilerinin üniversiteye uyum düzeylerinin farklı değişkenler açısından incelenmesi. Hasan Ali Yücel Ĕgitim Fakültesi Dergisi Sayl, 16 (2), 135-154.

Olgun, N., Öntürk, Z. K., Aslan, F.E., Karabacak, Ü., \& Serbest, Ş. (2010). Hemşirelik öğrencilerinin stresle başa çıkma düzeylerinin değerlendirilmesi: Bir yıllık izlem sonuçları. Hemşirelikte Eğitim ve Araştırma Dergisi, 7(2), 44-51.

Özkan S, \& Yılmaz E. (2010). Üniversite Öğrencilerinin Üniversite Yaşamına Uyum Durumları (Bandırma Örneği). Fırat Sağllk Hizmetleri Dergisi, 5(13), 154-169.

Pancer, S. M., Pratt, B. H., Michael, W. \& Alisat, S. (2000). Cognitive complexity of expectations and adjustment to university in the first year. Journal of Adolescent Research, 15, $38-57$ 
Paul, E. S. \& Brier, S. (2001). Friendsickness in the transition to college: Precollege predictors and college. Journal of Counseling and Development, 79(1), 77-89.

Sağel-Çetiner, E., Sayın-Karakaş, O.C., Şakiroğlu, M. (2018). Algilanan Stres ve Üniversiteye Uyum Süreci: Bilgece farkındalığın aracı rolü. Nesne, 6(3), 289-308.

Sawatzky, J.A. (1998). Understanding nursing students' stress: a proposed framework. Nurse Educ Today, 18,108-15.

Sevim, S. A., ve Yalçın, İ. (2006). Kısa süreli bir oryantasyon programı denemesi: Öğrencilerin uyum düzeyleri ve programa ilişkin görüşleri. Ankara Üniversitesi Eğitim Bilimleri Fakültesi Dergisi, 39 (2), 217-233.

Sevinç, S. (2010). Mersin Üniversitesi birinci sınıf öğrencilerinin kişisel ve kurumsal uyumlarını olumsuz etkileyen faktörlerin incelenmesi. Yayınlanmamış Yüksek Lisans Tezi. Mersin Üniversitesi Sosyal Bilimler Enstitüsü, Mersin.

Sevinç-Tuhanioğlu, S. (2017). Üniversite birinci sınıf öğrencilerinin üniversite yaşamına uyumlarına katkı sağlayan bireysel ve çevresel faktörlerin incelenmesi. Yayınlanmamıș doktora tezi, Mersin Üniversitesi, Eğitim Bilimleri Enstitüsü, Mersin

Sheu, S., Lin, H.S., Hwang, S.L. (2002). Perceived stress and physio-psycho-social status of nursing students during their initial period of clinical practice: the effect of coping behaviors. Int J Nurs Stud, 39,165-75.

Solberg, V. S., Valdez, J. ve Villarreal, P. (1994). Social support, stress, and hispanic college adjustment: Test of a diathesis-stress model. Hispanic Journal of Behavioral Sciences, 16(3), 230239.
Spady, G. W. (1970). Dropouts from higher education: An interdisciplinary review and synthesis. Interchange, 1 (1), 64-85.

Temel, E., Bahadır, A. and Çuhadır, D. (2007). Öğrenci hemşirelerin stresle baş etme tarzları ve depresyon düzeylerinin belirlenmesi. Firat Sağllk Hizmetleri Dergisi, 2(5), 107-118.

Terenzini, P. T., Lorang, W. G. \& Pascarella, E. T. (1981). Predicting freshman persistence and voluntary dropout decisions: A replication. Research in Higher Education, 15 (2), 109-127.

Thurber, C. \& Walton, E. (2012). Homesickness and Adjustment in University Students. Journal of American College Health, 60 (5), 1-5.

Tinto, V. (1975). Dropout from higher education: A Theoretical synthesis of recent research. Review of Educational Research, $45,89-125$.

Tinto, V. (1988). Stages of student departure: Reflections on the longitudinal character of student leaving. Journal of Higher Education, 59, 438-455.

Tinto, V. (1993). Leaving college: Rethinking the causes and cures of student attrition (2nd ed.). Chicago: The University of Chicago Press.

Tinto, V. (1997). Colleges as communities: Exploring the educational character of student persistence. Journal of Higher Education, 68 (6), 599-623

Woosley, S. A. \& Miller, A. (2009). Integration and institutional commitment as predictors of college student transition: Are third week indicators significant? College Student Journal, 43(4), 1260-1271. 